\title{
Phosphorus use efficiency by wheat plants that grown in an acidic soil
}

\author{
Rubya Shabnam ${ }^{1}$ and Md. Toufiq lqbal $2^{*}$
}

*Correspondence:

toufiq_iqbal@yahoo.com

${ }^{2}$ Department of Agronomy

and Agriculture Extension,

Faculty of Agriculture,

Rajshahi University, Rajshahi, Bangladesh

Full list of author information is available at the end of the article

\begin{abstract}
Phosphorus is a key Nutrient for plant growth and development. Phosphorus is taken up from the soil solution by plant roots as orthophosphate ions, principally as monovalent orthophosphate, $\mathrm{H}_{2} \mathrm{PO}_{4}{ }^{-}$ions. This study was conducted to explore the role of different phosphorus $(P)$ levels and $P$ uptake and use efficiency on acidic soils. The soil was collected from the acidic region of Bangladesh in which initial soil pH was 5.2 in water. $\mathrm{KH}_{2} \mathrm{PO}_{4}$ was used as the sources of phosphorus for the different level of $\mathrm{P}$ application. Two recently BARI developed wheat varieties like BARI GOM 25 and BARI GOM 26 was used a testing plant with three replications. Result showed the growth parameter, plant biomass increased about $91 \%$ (maximum at $120 \mathrm{mg} \mathrm{P} / \mathrm{kg}$ ) with respect to the controlled treatment. Likewise, P uptake by wheat seedlings increases about $90 \%$ (maximum at $120 \mathrm{mg} \mathrm{P} / \mathrm{kg}$ ) with respect to controlled treatment. However, no significant differences were observed between wheat varieties irrespective to growth and $P$ uptake by wheat seedlings. This study reveals that the elevated $P$ taken a significant part in the development of the wheat plant in acidic soil. These findings indicate that the added soluble $P$ increases the absorption of nutrients from the soil solution. However, application of elevated $P$ is efficient both for increasing shoot development and root growth and the phosphorus use efficiency with respect to plant utilization.
\end{abstract}

\section{Background}

Phosphorus (P) is an essential macro nutrient. It is vital to plant growth and is found in every living plant cell. It is involved in several key plant functions including energy transfer, photosynthesis, transformation of sugars and starches, nutrient movement within the plant and transfer of genetic characteristics from generation after generation (Pasek 2008). Low P availability is one of the major factors limiting crop production in acidic soils (Conde et al. 2014). The concentrations of inorganic P in soil solution are, however, typically very low, due to inorganic P's propensity to bind strongly to soil surfaces or form insoluble complexes with cations (Talboys et al. 2014). This means that inorganic $\mathrm{P}$ is often a limiting factor in plant growth and development. Phosphorus is taken up from the soil solution by plant roots as orthophosphateions, principally as monovalent orthophosphate, $\mathrm{H}_{2} \mathrm{PO}_{4}{ }^{-}$ions and to a lesser extent divalent orthophosphate, $\mathrm{HPO}_{4}{ }^{2-}$ ions (Armstrong 1999). Several factors can influence on both the rate and amount of $\mathrm{P}$ taken up by the plant and, therefore, elevated $\mathrm{P}$ can affect the recovery of a single application of $\mathrm{P}$ fertilizer. The same factors can also affect the recovery of $\mathrm{P}$ reserves accumulated in the soil from the past additions of $\mathrm{P}$ as fertilizer or manure 
(Syers et al. 2008). Application fertilizer e.g., wood ash alone, mineral P fertilizer plus lime or wood ash or localized applications of mineral $\mathrm{P}$ to a very small soil volume to achieve a better growth and $\mathrm{P}$ uptake of wheat in acid soils which are low in available $\mathrm{P}$ and have a high P fixation tendency (Melese et al. 2015).

Syers et al. (2008) reported in FAO (Food and Agriculture Organization) fertilizer and plant nutrient bulletin that the most important factors controlling the availability of $\mathrm{P}$ to plant roots are its concentration in the soil solution and the P-buffer capacity of the soil. The latter controls the rate at which $\mathrm{P}$ in the soil solution is replenished, i.e., the rate of desorption of $\mathrm{P}$ from the solid phase of the soil, which is faster in soils with a high buffer capacity. Also important are the size of the root system and the extent to which roots grow into the soil, and the efficiency with which roots take up P. When considered a single application of $\mathrm{P}$ fertilizer, its efficiency depends on how well it was mixed with the volume of exploited by the roots. Other factors that affect the crop yield, P uptake by the crop, recovery of $\mathrm{P}$ and its influence and efficiency include soil moisture and the extent of control of weeds, pests and diseases i.e., crop management. Because the effects of these factors vary from year to year, it is essential to average estimates of $\mathrm{P}$ recovery overa number of years in order to obtain reliable data. This study aims with the following objectives: to understand how elevated P behaves in an acidic soil, to determine P uptake by recently BARI released wheat varieties under acidic condition, evaluate growth response of recently BARI released wheat varieties under elevated $P$ applied condition. This study hypothesized that elevated P will help to utilized more P by the wheat plant even in acidic condition.

\section{Methods}

Soil and plant

Acidic soil collected form Thakurgaon district, Bangladesh was used as experimental soil. The initial soil $\mathrm{pH}$ was 5.2. The basic properties of soil are out-lined in Table 1. The BARI GOM-25 and BARI GOM-26 wheat varieties were used as a testing plant.

\section{Experimental design}

The CRD (completely Randomized Design) was adopted. The CRD experiment consisted of five levels of Phosphorus (P) like 0, 30, 60, 90 and $120 \mathrm{mg} \mathrm{P} / \mathrm{kg}$ and two wheat varieties- BARI GOM-25 and BARI GOM-26 with three replications. The $\mathrm{KH}_{2} \mathrm{PO}_{4}$ used as a $\mathrm{P}$ source. According to the treatment, the total amount of mono-potassium phosphate was calculated for different rates and a stock solution of $\mathrm{KH}_{2} \mathrm{PO}_{4}$ was prepared by diluting with DI water in a volumetric flask. To avoid the interactions between soil nutrients and added $\mathrm{P}$ no basal nutrients were added. The plants allowed growing for 28 days and they had to depend on the reserved food of the seeds and the added P for their growth.

Table 1 Properties of soils used in different experiments

\begin{tabular}{lllllll}
\hline $\begin{array}{l}\text { Soil } \\
\mathbf{p H}\end{array}$ & $\begin{array}{l}\text { Total } \\
\mathbf{N}(\%)\end{array}$ & $\begin{array}{l}\text { Available } \mathbf{P} \\
(\mathbf{p p m})\end{array}$ & $\begin{array}{l}\text { Exchangeable } \\
\mathbf{K}(\mathbf{C m o l} / \mathbf{K g})\end{array}$ & $\begin{array}{l}\text { Available S } \\
(\mathbf{p p m})\end{array}$ & $\begin{array}{l}\text { Available } \mathbf{Z n} \\
(\mathbf{p p m})\end{array}$ & $\begin{array}{l}\text { Organic matter } \\
(\%)\end{array}$ \\
\hline 5.2 & 0.05 & 10.2 & 0.2 & 19.5 & 0.59 & 0.85 \\
\hline
\end{tabular}


The soil was incubated at $30{ }^{\circ} \mathrm{C}$ for 7 days then $\mathrm{KH}_{2} \mathrm{PO}_{4}$ as per $\mathrm{P}$ doses were applied directly to the soil in each cup and mixed thoroughly before sowing. The total experiment was conducted in Research laboratories, Department of Agronomy and Agricultural Extension, Rajshahi University, Rajshahi, Bangladesh.

\section{Seed germination and plant sowing}

Seeds of uniform size were selected for germination. The seeds BARI GOM-25 and BARI GOM-26 were germinated in moist sand in two separate petridishes in dark at $25^{\circ} \mathrm{C}$ for $70 \mathrm{~h}$. Five holes $(1.0 \mathrm{~cm}$ deep and $1.0 \mathrm{~cm}$ wide) were made in the soil in each plastic cup containing $200 \mathrm{~g}$ pre-incubated soil. Keeping the radicals in down ward direction five pre-germinated seeds of BARI GOM-25 and BARI GOM-26 were placed carefully in those holes in each cup and then the seeds were gently covered with the same treated soil. The BARI GOM-25 and BARI GOM-26 were placed in separated cups. After sowing, each cup was covered by filter paper for first two (2) days to avoid disturbance of top soil. Deionized (DI) water was sprayed on the filter paper to keep the soil moist. To maintain the required soil moisture content $20 \mathrm{ml}$ DI water was added every day to each cup during the growth period of wheat plants and watering was stopped 3 days before harvesting.

\section{Plant growth condition}

Plants were grown in open air under $10 \mathrm{~h}$ dark and $14 \mathrm{~h}$ light conditions. The variations of day and night temperature were $20-30$ and $15-20{ }^{\circ} \mathrm{C}$ respectively. All the cups were re-randomized in their position on alternate days during the growing period of wheat seedlings, to minimize the positional effects.

\section{Plant harvesting}

Plants were harvested 27 days after sowing. Whole plants with roots and surrounding soil were removed from each cup by gentle agitating to provide minimum disturbance to the roots and shoots. Intact plants were then lifted up gently from the soil and shaken lightly to remove the bulk soil and then washed to remove the adhered soil from roots. Collected bulk soil was air-dried and stored in a controlled room temperature $\left(25^{\circ} \mathrm{C}\right)$ until analysis. Shoots and roots were separated. Shoots were oven dried at $70{ }^{\circ} \mathrm{C}$ for 3 days and stored for analysis. The harvested roots were washed with DI water and ovendried at $70{ }^{\circ} \mathrm{C}$ temp for 3 days and stored for analysis.

\section{Phosphorus determination in soil and plant tissue}

The amounts of $\mathrm{P}$ in root, shoot and soil were determined. After digestion in a mixture of concentrated nitric and percloric acids (4:1), the concentration of $\mathrm{P}$ in root and shoot materials were determined. Concentration of $\mathrm{P}$ in root and shoot materials were determined using the vanadomolybdate method after digestion in a mixture of concentrated nitric and perchloric acids (4:1) (Zheng et al. 2005). Colorimetric method for the determination of phosphorous concentrations in digest solutions was used. This method is called the molydovanado-phosphate method (AOAC 1975). Briefly, phosphorous was assayed using the molydovanado-phosphate method adding $3-\mathrm{ml}$ digested solution, 
2-ml reagent and 5-ml DI water. The absorbance reading was used at $470 \mathrm{~nm}$ (Iqbal et al. 2010).

\section{Statistical analysis}

Shoot and root parameters were analyzed by two-way ANOVA (Treatment $\times$ Variety), total $\mathrm{P}$ up take as well as distribution of $\mathrm{P}$ in different plant parts were determined by one-way ANOVA using Genstat 11th edition for Windows (Lawes Agricultural Trust, $\mathrm{UK})$.

\section{Phosphorus use efficiency calculation}

Phosphorus use efficiency was calculated using the formulae as described by Fageria et al. (1997).

$$
\text { PUE\% }=\frac{\text { Total P uptake }\left(\frac{\mathrm{mg}}{\mathrm{kg}}\right) \text { in Treatment pot }- \text { Total P uptake }\left(\frac{\mathrm{mg}}{\mathrm{kg}}\right) \text { in control pot }}{P \text { dose applied }\left(\frac{\mathrm{mg}}{\mathrm{kg}}\right)} \times 100
$$

Total P uptake $(\mathrm{mg} / \mathrm{kg})=\mathrm{P}$ uptake by root $(\mathrm{mg} / \mathrm{kg})+\mathrm{P}$ uptake by shoot $(\mathrm{mg} / \mathrm{kg})$.

\section{Measurements of soil physical and chemical properties}

Soil textural analysis was conducted by using an abbreviated version of the international pipette method. Clay content was determined by a pipette method after pretreatment with $\mathrm{H}_{2} \mathrm{O}_{2}$ to remove organic matter (Gee and Bauder 1986). The $\mathrm{pH}$ of the soil was determined before incubation experiment in deionised water using a soil-to-solution ratio of 1:2.5. Organic carbon of the soil samples was determined by wet oxidation method (Walkley and Black 1934). Soil organic matter content was determined by multiplying the percent value of organic carbon with the conventional Van-Bemmelen's factor of 1.724 (Piper 1950). The nitrogen content of the soil sample was determined by distilling soil with alkaline potassium permanganate solution (Subhaiah and Asija 1956). The distillate was collected in $20 \mathrm{ml}$ of $2 \%$ boric acid solution with methylred and bromocresol green indicator and titrated with $0.02 \mathrm{~N}$ sulphuric acid $\left(\mathrm{H}_{2} \mathrm{SO}_{4}\right)$ (Podder et al. 2012). Soil available $S$ ( $\mathrm{ppm}$ ) was determined by calcium phosphate extraction method with a spectrophotometer at $535 \mathrm{~nm}$ (Petersen 1996). The soil available K was extracted with $1 \mathrm{~N} \mathrm{NH}_{4} \mathrm{OAC}$ and determined by an atomic absorption spectrometer (Biswas et al. 2012). The available $P$ of the soil was determined by spectrophotometer at a wavelength of $890 \mathrm{~nm}$. The soil sample was extracted by Olsen method with $0.5 \mathrm{M} \mathrm{NaHCO}_{3}$ as outlined by Huq and Alam (2005). Zn in the soil sample was measured by an atomic absorption spectrophotometer (AAS) after extracting with DTPA (Soltanpour and Workman 1979).

\section{Results}

All the plant growth and $P$-uptake parameters were highly significant $(P \leq 0.001)$ under $P$ levels (Table 2). Similarly, significant differences between varieties were observed in relation to all the growth and P-uptake parameters. 
Table 2 Significance levels for the main and interactive effect of $P$ and varieties on seedlings growth

\begin{tabular}{llllll}
\hline $\begin{array}{l}\text { Source } \\
\text { of variation }\end{array}$ & $\begin{array}{l}\text { Plant } \\
\text { height }\end{array}$ & $\begin{array}{l}\text { Shoot dry } \\
\text { weight }\end{array}$ & $\begin{array}{l}\text { P concentration } \\
\text { in shoot }\end{array}$ & $\begin{array}{l}\text { Root dry } \\
\text { weight }\end{array}$ & $\begin{array}{l}\text { P uptake } \\
\text { in root }\end{array}$ \\
\hline Treatment $(T)$ & $* * *$ & $* * *$ & $* * *$ & $* * *$ & $* * *$ \\
Variety $(\mathrm{V})$ & $* * *$ & n.s. & $* *$ & n.s. & $* *$ \\
$T \times V$ & $* * *$ & n.s. & - & n.s. & - \\
\hline
\end{tabular}

Where n.s., ${ }^{* *}$ and ${ }^{* * *}$ represent probability of $>0.05, \leq 0.01$ and $\leq 0.001$, respectively. ${ }^{-}$' indicates no data available

\section{Effect on plant height}

Plant height is a genetic character of a variety but its potential can be achieved by adequate crop management. The data on the effect of different P levels on plant height is given in Fig. 1. The results showed for the variety BARI GOM 25 that the maximum plant height $(34.7 \mathrm{~cm})$ was recorded in treatment T5 $(120 \mathrm{mg} \mathrm{P} / \mathrm{kg})$, while it was minimum $(25.49 \mathrm{~cm})$ in treatment T1 (control). Again, the results showed for the variety BARI GOM 26 that the maximum plant height $(34.93 \mathrm{~cm})$ was recorded in treatment T5 $(120 \mathrm{mg} \mathrm{P} / \mathrm{kg}$ ), while it was minimum $(26.06 \mathrm{~cm})$ in treatment T1 (control). Plant height was significantly $(P \leq 0.001)$ affected among all the various $\mathrm{P}$ application and variety of wheat plant. It also increased with the increasing level of phosphorus application. Hence, among low level of various phosphorous applications, Phosphorous had the gradual increasing effect on plant height with increasing $\mathrm{P}$ applications, while at high level $\mathrm{P}$ resulted in maximum plant height.

\section{Shoot dry weight}

As like plant height, the shoot biomass showed similar trend under different $\mathrm{P}$ applications. The results showed for the variety BARI GOM 25 that the maximum shoot biomass $(0.85 \mathrm{gm} / \mathrm{pot})$ was recorded in treatment $\mathrm{T} 5(120 \mathrm{mg} \mathrm{P} / \mathrm{kg})$, while it was minimum $(0.45 \mathrm{gm} / \mathrm{pot})$ in treatment $\mathrm{T} 1$ (control). Again, the results showed for the variety BARI GOM 26 that the maximum shoot biomass $(0.87 \mathrm{gm} / \mathrm{pot})$ was recorded in treatment T5 $(120 \mathrm{mg} \mathrm{P} / \mathrm{kg})$, while it was minimum $(0.47 \mathrm{gm} / \mathrm{pot})$ in treatment T1 (control). The shoot biomass was significantly $(\mathrm{P} \leq 0.001)$ affected among all the various $\mathrm{P}$ applications

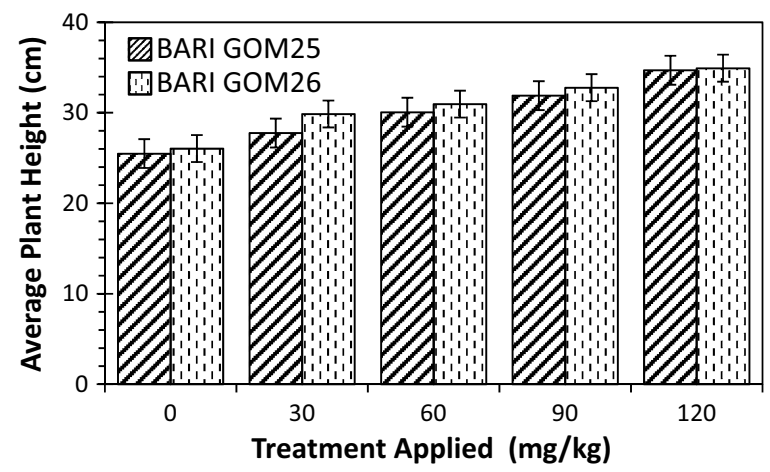

Fig. 1 Effect of $P$ application on average plant height of the wheat seedlings was grown in various level of $P$ for 28 days 
on wheat plant. Also, the shoot biomass did not significantly $(P>0.05)$ differed between varieties of wheat plant. The shoot biomass also increased with the increasing level of phosphorus application (Fig. 2).

\section{Root dry weight}

Total root biomass varied among all the treatments. Total root biomass in BARI GOM 26 were the highest and the lowest in Treatment T5 $(0.67 \mathrm{gm} / \mathrm{pot})$ and Treatment T1 ( $0.32 \mathrm{gm} / \mathrm{pot})$ respectively, followed by gradual increase in Treatments T2 $(0.42 \mathrm{gm} / \mathrm{pot})$, T3 (0.56 gm/pot) and Treatment T4 (0.61 gm/pot) (Fig. 3). Again, for BARI GOM 25 total root biomass were the highest and the lowest in Treatment T5 $(0.65 \mathrm{gm} / \mathrm{pot})$ and Treatment T1 $(0.30 \mathrm{gm} / \mathrm{pot})$ respectively, followed by gradual increase in Treatments T2 (0.40 gm/pot), T3 (0.55 gm/pot) and Treatment T4 (0.60 gm/pot). Similar to shoot dry weight, root biomass was significantly $(P \leq 0.001)$ affected among all the various $P$ application on wheat plant. But, the root biomass did not significantly $(P>0.05)$ differed between varieties of wheat plant. The root biomass also increased with the increasing level of phosphorus application (Fig. 3).

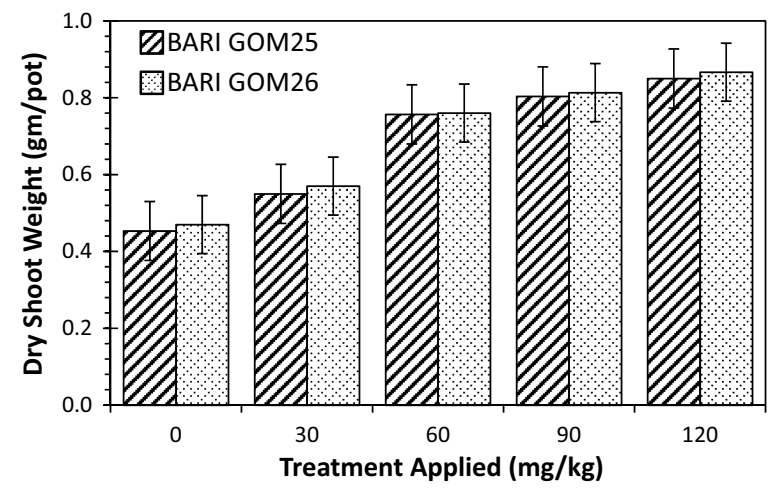

Fig. 2 Effect of $P$ application on dry shoot weight of the wheat seedlings was grown in various level of $P$ for 28 days

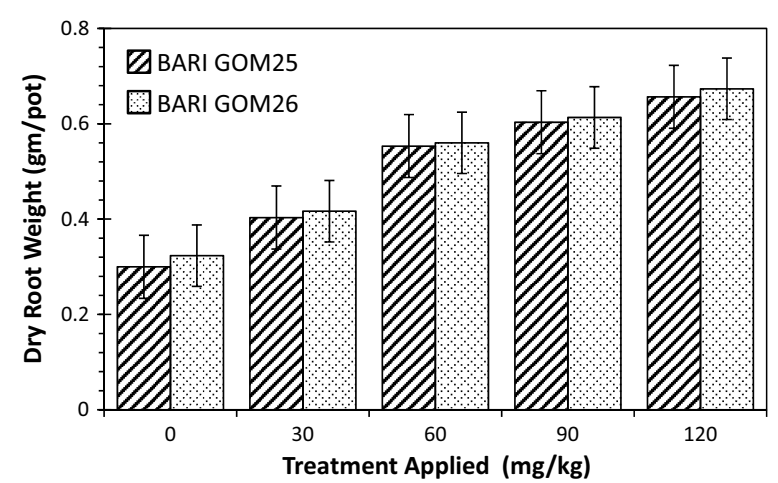

Fig. 3 Effect of $P$ application on dry root weight of the wheat seedlings was grown in various level of $P$ for 28 days 


\section{Shoot $\mathrm{P}$ uptake}

In general, shoot $\mathrm{P}$ uptake was found in increasing trend under different $\mathrm{P}$ application on wheat plant. Shoot $\mathrm{P}$ uptake was significantly $(P \leq 0.001)$ affected among all the various $\mathrm{P}$ applications on wheat plant. Total shoot $\mathrm{P}$ uptake in BARI GOM 26 were the highest and the lowest in Treatment T5 $(4.53 \mathrm{gm} / \mathrm{kg})$ and Treatment T1 $(0.41 \mathrm{gm} / \mathrm{kg})$ respectively, followed by gradual increase in Treatments T2 $(1.36 \mathrm{gm} / \mathrm{kg}), \mathrm{T} 3(3.87 \mathrm{gm} / \mathrm{kg})$ and Treatment T4 (4.44 gm/kg) (Fig. 4). Again, for BARI GOM 25 total shoot P uptake were the highest and the lowest in Treatment T5 $(4.49 \mathrm{gm} / \mathrm{kg})$ and Treatment T1 $(0.40 \mathrm{gm} / \mathrm{kg})$ respectively, followed by gradual increase Treatments T2 $(1.29 \mathrm{gm} / \mathrm{kg})$, T3 $(3.79 \mathrm{gm} / \mathrm{kg})$ and Treatment T4 (4.37 gm/ $\mathrm{kg})$. The shoot P uptake of BARI GOM 25 and BARI GOM 26 was dependent on the treatments. However, the two varieties had similar responses on shoot P uptake in the different treatments (Fig. 4).

\section{Root $\mathrm{P}$ uptake}

In general, root $\mathrm{P}$ uptake was found in increasing trend under different $\mathrm{P}$ application on wheat plant. Root $\mathrm{P}$ uptake was significantly $(P \leq 0.001)$ affected among all the various $\mathrm{P}$ application on wheat plant. Total root $\mathrm{P}$ uptake in BARI GOM 26 were highest and the lowest in Treatment T5 $(2.11 \mathrm{gm} / \mathrm{kg})$ and Treatment T1 $(0.31 \mathrm{gm} / \mathrm{kg})$ respectively, followed by gradual increase in Treatments T2 $(0.66 \mathrm{gm} / \mathrm{kg})$, T3 $(1.57 \mathrm{gm} / \mathrm{kg})$ and Treatment T4 (1.87 gm/kg) (Fig. 5). Again, for BARI GOM 25 total root P uptake were the highest and the lowest in Treatment T5 $(2.07 \mathrm{gm} / \mathrm{kg})$ and Treatment T1 $(0.27 \mathrm{gm} / \mathrm{kg})$, followed by gradual increase Treatments T2 $(0.63 \mathrm{gm} / \mathrm{kg}), \mathrm{T} 3(1.53 \mathrm{gm} / \mathrm{kg})$ and Treatment T4 $(1.85 \mathrm{gm} / \mathrm{kg})$. The root P uptake of BARI GOM 25 and BARI GOM 26 was dependent on the treatments. However, the two varieties had similar responses on root $P$ uptake in the different treatments (Fig. 5).

\section{Total $\mathrm{P}$ uptake and $\mathrm{P}$ distribution}

In both varieties of BARI GOM 25 and BARI GOM 26 were found similar trend in total P uptake. The total P uptake by plant was significantly high in Treatment T5 from other treatments in both varieties. However, total $P$ uptake was about nine times greater in Treatment T5 than control Treatment T1. The total P uptake was greater in BARI GOM 26 than BARI GOM 25 in all treatments. Total P uptake in BARI GOM 26 were

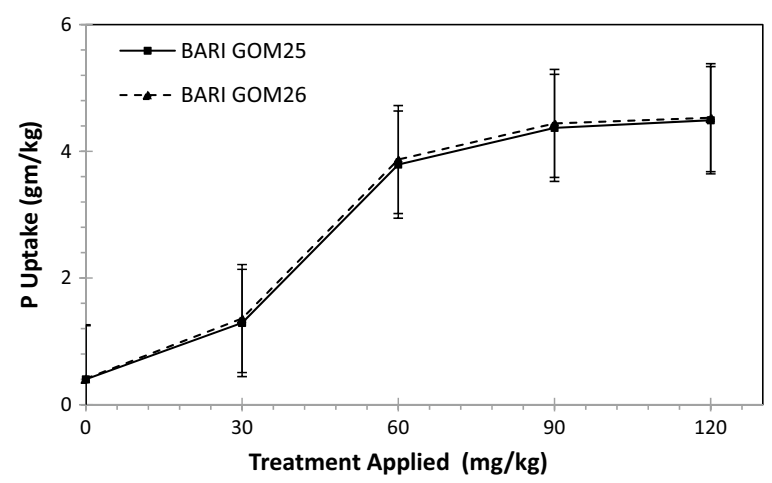

Fig. 4 Effect of P application on P uptake of wheat shoot in various level of P for 28 days 


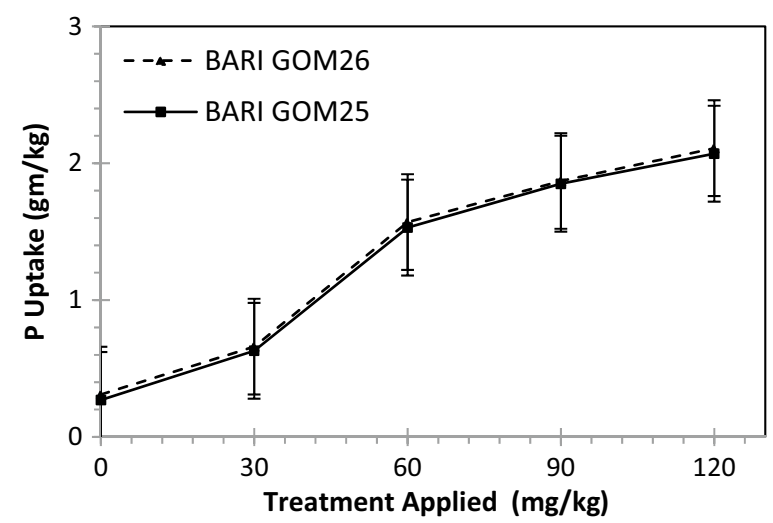

Fig. 5 Effect of $P$ application on $P$ uptake of wheat root in various level of $P$ for 28 days

the highest in Treatment T5 $(6.64 \mathrm{gm} / \mathrm{kg})$ and the lowest in Treatment T1 $(0.72 \mathrm{gm} / \mathrm{kg})$ respectively, followed by gradual increase in Treatments T2 $(2.02 \mathrm{gm} / \mathrm{kg}), \mathrm{T} 3(5.44 \mathrm{gm} /$ $\mathrm{kg}$ ) and Treatment T4 (6.31 gm/kg) (Fig. 6). Again, for BARI GOM 25 total P uptake were the highest in Treatment T5 $(6.56 \mathrm{gm} / \mathrm{kg})$ and the lowest in Treatment T1 $(0.67 \mathrm{gm} / \mathrm{kg})$ respectively, followed by gradual increase in Treatments T2 $(1.92 \mathrm{gm} / \mathrm{kg}), \mathrm{T} 3(5.32 \mathrm{gm} /$ $\mathrm{kg}$ ) and Treatment T4 (6.22 gm/kg) (Fig. 6).

\section{$P$ use efficiency in wheat plant}

Data of P use efficiency (PUE) of wheat are given in Table 3. PUE was calculated in terms of $\mathrm{P}$ uptake per unit of $\mathrm{P}$ application. The results revealed that lower PUE was seen at higher P rates. The maximum PUE of $7.75 \%$ was observed at $60 \mathrm{mg} / \mathrm{kg} P$ rate for variety BARI GOM 25 and it decreased significantly at higher P rates. Similarly, the maximum PUE of $7.95 \%$ was observed at $60 \mathrm{mg} / \mathrm{kg}$ P rate for variety BARI GOM 26 and it decreased significantly at higher P rates. Again, variety significantly affected the PUE and the minimum of $4.17 \%$ was obtained with $30 \mathrm{mg} / \mathrm{kg}$ P application for variety BARI GOM 25 and $4.50 \%$ was obtained with $30 \mathrm{mg} / \mathrm{kg}$ P application for variety BARI GOM 26. Results are in conformity with those of Rahim et al. (2010) who concluded that wheat

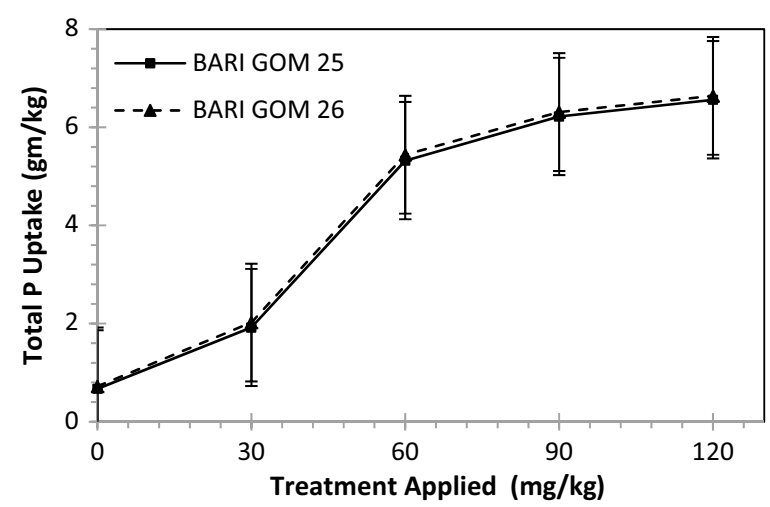

Fig. 6 Effect of $\mathrm{P}$ application on $\mathrm{P}$ uptake of wheat plant in various level of $\mathrm{P}$ for 28 days 
Table $3 \mathrm{P}$ concentration in root, $\mathrm{P}$ concentration in shoot, and $\mathrm{P}$ use efficiency of two wheat varieties across different $P$ levels

\begin{tabular}{llcllll}
\hline Variety & Treatment & $\begin{array}{l}\text { P rate } \\
(\mathbf{m g} / \mathbf{k g})\end{array}$ & $\begin{array}{l}\mathbf{P} \text { in shoot } \\
(\mathbf{g m} / \mathbf{k g})\end{array}$ & $\begin{array}{l}\mathbf{P} \text { in root } \\
(\mathbf{g m} / \mathbf{k g})\end{array}$ & $\begin{array}{l}\text { Total P uptake } \\
(\mathbf{g m} / \mathbf{k g})\end{array}$ & $\begin{array}{l}\text { P use efficiency, } \\
\text { PUE (\%) }\end{array}$ \\
\hline BARI GOM 25 & T1 & 0 & 0.40 & 0.27 & 0.67 & 0.00 \\
& T2 & 30 & 1.29 & 0.63 & 1.92 & 4.17 \\
& T3 & 60 & 3.79 & 1.53 & 5.32 & 7.75 \\
& T4 & 90 & 4.37 & 1.85 & 6.22 & 6.17 \\
BARI GOM 26 & T5 & 120 & 4.49 & 2.07 & 6.56 & 4.91 \\
& T1 & 0 & 0.41 & 0.31 & 0.72 & 0.00 \\
& T2 & 30 & 1.36 & 0.66 & 2.02 & 4.50 \\
& T3 & 60 & 3.87 & 1.57 & 5.44 & 7.95 \\
& T4 & 90 & 4.44 & 1.87 & 6.31 & 6.27 \\
& T5 & 120 & 4.53 & 2.11 & 6.64 & 4.98 \\
\hline
\end{tabular}

growth increased significantly with the use of P. However, it is clear from Table 3 that elevated P application has significant influence the PUE of wheat plant.

\section{Root-shoot ratio of wheat plant}

Root-shoot ratio is one of several ratios, which give estimates of the distribution of dry matter between the different plant organs. It is a measure of the distribution of dry matter between the root and the shoot systems and it is a good indicator for effects on root and shoots dry weights. The results (Table 4) showed that root-shoot ratio an increase with the increasing P application in both varieties of BARI released wheat plants. Such increase in root-shoot ratio indicates that the proportion of dry matter allocated to roots was increased compared to the shoots. The root-shoot ration in BARI GOM 26 were the highest in Treatment T5 (0.78) and the lowest in Treatment T1 (0.69) respectively, followed by gradual increase in Treatments T2 (0.73), T3 (0.74) and Treatment T4 (0.75). Again, for BARI GOM 25 the ratio were the highest in Treatment T5 (0.77) and the lowest in Treatment T1 (0.66) respectively, followed by gradual increase in Treatments T2 (0.73), T3 (0.73) and Treatment T4 (0.75). The root-shoot ratios increase with

\begin{tabular}{|c|c|c|c|c|c|}
\hline \multirow[t]{2}{*}{ Variety } & \multirow[t]{2}{*}{ Treatment } & \multirow[t]{2}{*}{$P$ rate $(\mathrm{mg} / \mathrm{kg})$} & \multicolumn{2}{|c|}{$\begin{array}{l}\text { Biomass production } \\
\text { (gm/pot) }\end{array}$} & \multirow[t]{2}{*}{ Root-shoot ratio } \\
\hline & & & Shoot & Root & \\
\hline \multirow[t]{5}{*}{ BARI GOM 25} & $\mathrm{~T} 1$ & 0 & 0.45 & 0.30 & 0.66 \\
\hline & $\mathrm{T} 2$ & 30 & 0.55 & 0.40 & 0.73 \\
\hline & T3 & 60 & 0.76 & 0.55 & 0.73 \\
\hline & T4 & 90 & 0.80 & 0.60 & 0.75 \\
\hline & T5 & 120 & 0.85 & 0.66 & 0.77 \\
\hline \multirow[t]{5}{*}{ BARI GOM 26} & $\mathrm{~T} 1$ & 0 & 0.47 & 0.32 & 0.69 \\
\hline & $\mathrm{T} 2$ & 30 & 0.57 & 0.42 & 0.73 \\
\hline & T3 & 60 & 0.76 & 0.56 & 0.74 \\
\hline & $\mathrm{T} 4$ & 90 & 0.81 & 0.61 & 0.75 \\
\hline & T5 & 120 & 0.87 & 0.67 & 0.78 \\
\hline
\end{tabular}


time means roots have preferential utilization of photosynthates under the elevated $\mathrm{P}$ conditions.

\section{Discussion}

\section{Effects of elevated phosphorus application on acid soils}

In general, plants grow better when partially soluble phosphate is applied in comparison to the soluble P source. Again, Rubio et al. (2003) discussed that soil P stability and availability influenced by soil $\mathrm{pH}$. Soil $\mathrm{pH}$ influences the charge of the P species in solution as well as the charge of the adsorbing particles in soils. When $\mathrm{pH}$ rises, an increase in the negative charge is produced thereby decreasing $\mathrm{P}$ adsorption; but, at the sametime, an increase in $\mathrm{HPO}_{4}{ }^{2-}$ concentration is produced which has a much greater affinity for reactive soil surfaces which in turn increases $\mathrm{P}$ adsorption (Schachtman et al. 1998). Whether a change in soil $\mathrm{pH}$ will increase or decrease $\mathrm{P}$ in soil solution sometimes depends on effect dominant (Whitelaw 2000). Therefore, below $\mathrm{pH}$ 6.0, most $\mathrm{P}$ will be present as the monovalent $\mathrm{H}_{2} \mathrm{PO}_{4}{ }^{-}$species, whereas $\mathrm{H}_{3} \mathrm{PO}_{4}$ and $\mathrm{HPO}_{4}{ }^{2-}$ will be present only in minor proportions. Most studies on the $\mathrm{pH}$ dependence of $\mathrm{P}$ uptake in higher plants have revealed that uptake rates are highest between $\mathrm{pH} 5.0$ and 6.0, where $\mathrm{H}_{2} \mathrm{PO}_{4}{ }^{-}$dominates (Ullrich-Eberius et al. 1984; Furihata et al. 1992), which suggests that $\mathrm{P}$ is taken up as themonovalent form. The study was conducted in acidic soil and $\mathrm{P}$ doses were applied directly to the soil. The maximum Phosphorus use efficiency of $7.75 \%$ was observed at $60 \mathrm{mg}$ P/kg rate for variety BARI GOM 25 and it decreased significantly at higher P rates. Similarly, the maximum Phosphorus use efficiency of $7.95 \%$ was observed at $60 \mathrm{mg}$ P/kg rate for variety BARI GOM 26 and it decreased significantly at higher $P$ rates. Results indicate that plant growth increased significantly with the use of P. However, it is clear from Fig. 7 that elevated P application has significant influence the PUE of wheat plant.

\section{Phosphorus uptake efficiency by wheat plant under acidic soil condition}

After harvesting, the shoot $\mathrm{P}$ uptake amounts of the different treatments were compared. At low level of P supply, shoot P uptake was significantly increased in comparison with

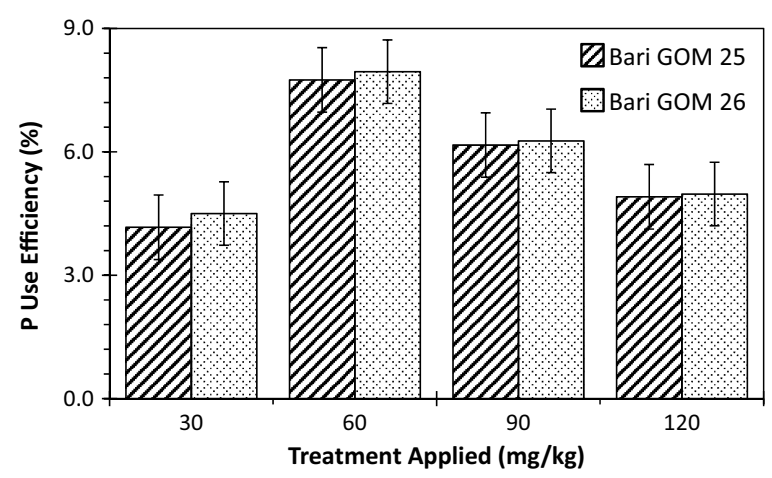

Fig. 7 P use efficiency of two wheat varieties across different P levels 
the controlled treatment (Fig. 4). At high levels of available P, there were no significant differences among all treatments. Similar results were observed in different genotypes of wheat (Fageria and Baligar 1999; Ahmad et al. 2013; Hu et al. 2014). Total shoot P uptake in BARI GOM 26 of Treatment T2 increased $70 \%(1.36 \mathrm{gm} / \mathrm{kg})$ in comparison with the controlled Treatment T1 $(0.41 \mathrm{gm} / \mathrm{kg})$. Similar trend was found in T3 $65 \%$ (3.87 gm/ $\mathrm{kg})$ in comparison of T2. But, at high levels of available P, in Treatment T4 and Treatment T5 the shoot P uptake increased 13 and $2 \%$ respectively. Again, for BARI GOM 25 total soot P uptake in Treatment T2 was increased $69 \%$ (1.29 gm $/ \mathrm{kg})$ in comparison with the controlled Treatment T1 (0.40 gm/ $/ \mathrm{kg})$. Similar trend was found in T3 $66 \%$ (3.79 gm/ $\mathrm{kg})$ in comparison of T2. But, at high levels of available P, in Treatment T4 and Treatment T5 the shoot $\mathrm{P}$ uptake increased 13 and $3 \%$ respectively. This is in line with the suggestion of Cavagnaro et al. (2003) that, P uptake by plant shoot was significantly high at low $\mathrm{P}$ concentration.

During collection, the root $\mathrm{P}$ uptake measures of the diverse treatments were analyzed. At low level of $\mathrm{P}$ supply, root $\mathrm{P}$ uptake was primarily found increase in examination with the controlled treatment (Fig. 5). At elevated amounts of accessible P, there was no noteworthy contrast among all treatments. Comparative results were reported in different genotypes of wheat (Fageria and Baligar 1999; Ahmad et al. 2013; Hu et al. 2014). Aggregate root P uptake in BARI GOM 26 of Treatment T2 increased 53 \% (0.66 gm/ $\mathrm{kg})$ in correlation with the controlled Treatment T1 $(0.31 \mathrm{gm} / \mathrm{kg})$. Comparable pattern was found in T3 $58 \%(1.57 \mathrm{gm} / \mathrm{kg})$ in correlation of Treatment T2. Yet, at high levels of accessible P, in Treatment T4 and Treatment T5 the root P uptake was expanded 16 and $11 \%$ individually. For BARI GOM 25 aggregate root P uptake in Treatment T2 increased $57 \%(0.63 \mathrm{gm} / \mathrm{kg})$ in examination compared with the controlled Treatment T1 $(0.27 \mathrm{gm} /$ $\mathrm{kg})$. Comparative pattern was found in T3 $59 \%(1.53 \mathrm{gm} / \mathrm{kg})$ in examination of Treatment T2. However, at high levels of accessible P, in Treatment T4 and Treatment T5 the root $\mathrm{P}$ uptake increased 17 and $11 \%$ separately. This is in accordance with the recommendation of Cavagnaro et al. (2003) that, P uptake by plant root was significantly high at low $\mathrm{P}$ concentration.

The plant P uptake measures of the various treatments were investigated. Similar to the shoot and root phosphorus uptake pattern total plant phosphorus uptake results were compared with different treatments. Total plant P uptake in BARI GOM 26 of Treatment T2 increased $64 \%$ (2.02 gm/ $\mathrm{kg})$ in relationship with the controlled Treatment T1 $(0.72 \mathrm{gm} / \mathrm{kg})$. Similar example found in T3 $63 \%(5.44 \mathrm{gm} / \mathrm{kg})$ in connection of Treatment T2. At high levels of accessible P, in Treatment T4 and Treatment T5 the plant P uptake increased 14 and $5 \%$ independently. Again, for BARI GOM 25 total plant P uptake in Treatment T2 was extended $65 \%(1.92 \mathrm{gm} / \mathrm{kg})$ in examination with the controlled Treatment T1 $(0.67 \mathrm{gm} / \mathrm{kg})$. Similar example found in T3 64 \% (5.32 gm/ $\mathrm{kg}$ ) in examination of treatment $\mathrm{T} 2$. On the other hand, at large levels of available $\mathrm{P}$, in 
Treatment T4 and Treatment T5 the plant P uptake was extended 14 and $5 \%$ independently. Thus, $\mathrm{P}$ uptake by plant was on a very basic level high at low $\mathrm{P}$ concentration.

The relationship between shoot $\mathrm{P}$ uptake and average plant height was analyzed to investigate the $\mathrm{P}$ taken up by plants. A significant correlation $\left(\mathrm{R}^{2}=0.87, P<0.05\right)$ between plant height and shoot $\mathrm{P}$ uptake under elevated $\mathrm{P}$ supply indicated that plant development enhances with the application of $P$ in soil (Fig. 8). Similarly, a significant correlation $\left(R^{2}=0.93, P<0.05\right)$ between plant height and root $P$ uptake under elevated $\mathrm{P}$ application was observed. The relationship indicates that increase of the $\mathrm{P}$ uptake plant height increases with elevated $\mathrm{P}$ application which makes increasing absorption of nutrients from soil solution.

\section{Growth response of wheat plant for elevated $\mathrm{P}$ application in acid soils}

To investigate growth response of recently BARI released wheat varieties under elevated $\mathrm{P}$ applied condition, all growth measurements, including root biomass, plant height and shoot biomass measures were taken. The highly significant Treatment $(\mathrm{T})$ interaction for shoot growth $(\mathrm{P} \leq 0.001)$ in this study indicates that the shoot growth responses of
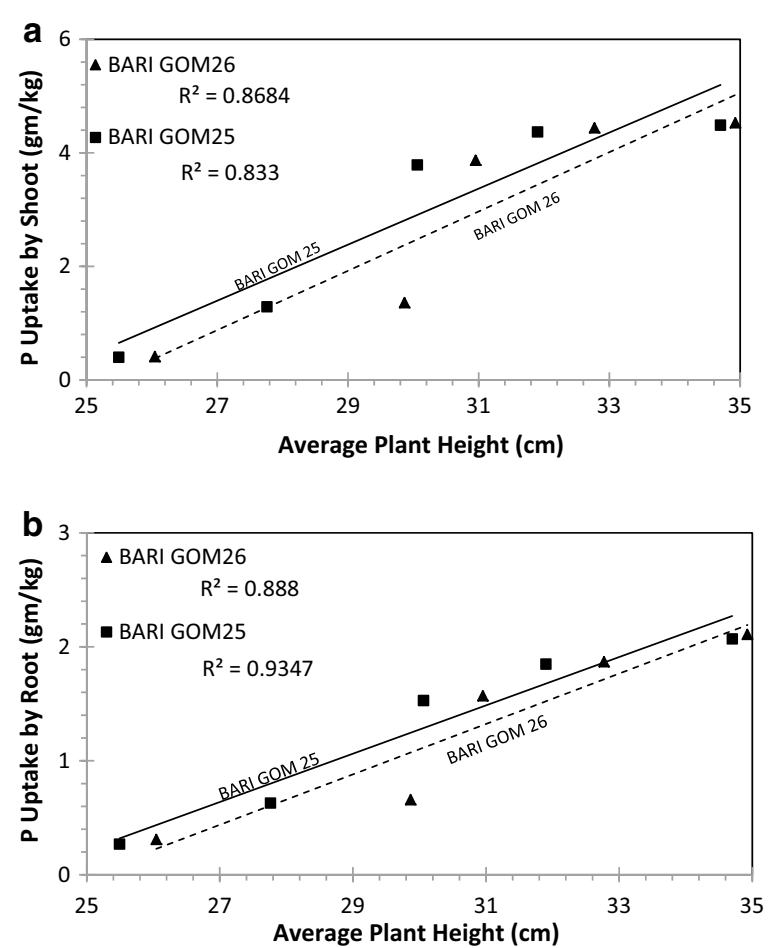

Fig. 8 Relationship between a $\mathrm{P}$ uptake by shoot and average plant height; $\mathbf{b} \mathrm{P}$ uptake by root and average plant height of wheat plant 
BARI GOM 25 and BARI GOM 26 seedlings were dependent on the level of added P. In all treatments, there were no significant differences between BARI GOM 25 and BARI GOM 26 seedlings for any growth measurement. The results showed for the variety BARI GOM 25 that the maximum plant height $(34.7 \mathrm{~cm})$ was recorded in treatment T5 $(120 \mathrm{mg} \mathrm{P} / \mathrm{kg})$, while it was minimum $(25.49 \mathrm{~cm})$ in treatment T1 (control). Again, the results showed for the variety BARI GOM 26 that the maximum plant height $(34.93 \mathrm{~cm})$ was recorded in treatment T5 $(120 \mathrm{mg} \mathrm{P} / \mathrm{kg})$, while it was minimum $(26.06 \mathrm{~cm})$ in treatment T1 (control). Thus, plant height was significantly $(P \leq 0.001)$ affected among all the various $P$ application and variety of wheat plant.

The shoot biomass was also significantly $(\mathrm{P} \leq 0.001)$ affected among all the various $\mathrm{P}$ applications on wheat plant. The results showed for the variety BARI GOM 25 that the maximum shoot biomass $(0.85 \mathrm{gm} / \mathrm{pot})$ was recorded in treatment T5 $(120 \mathrm{mg} \mathrm{P} /$ $\mathrm{kg})$, while it was minimum $(0.45 \mathrm{gm} / \mathrm{pot}$ ) in treatment T1 (control). Again, the findings indicated for the variety BARI GOM 26 that the maximum shoot biomass $(0.87 \mathrm{gm} / \mathrm{pot})$ was in treatment T5 $(120 \mathrm{mg} \mathrm{P} / \mathrm{kg})$, while it was minimum $(0.47 \mathrm{gm} / \mathrm{pot})$ in treatment T1 (control).

Investigation of another growth parameter showed that total root biomass varied among the treatments. The root biomass in BARI GOM 26 were the highest in Treatment T5 $(0.67 \mathrm{gm} / \mathrm{pot})$ and the lowest in Treatment T1 (control) $(0.32 \mathrm{gm} / \mathrm{pot})$ respectively, followed by gradual increase in Treatments T2 $(0.42 \mathrm{gm} / \mathrm{pot}), \mathrm{T} 3(0.56 \mathrm{gm} / \mathrm{pot})$ and Treatment T4 (0.61 gm/pot). Again, for BARI GOM 25 total root biomass were the highest in Treatment T5 $(0.65 \mathrm{gm} /$ pot $)$ and the lowest in Treatment T1 $(0.30 \mathrm{gm} /$ pot $)$ respectively, followed by gradual increases in Treatments T2 $(0.40 \mathrm{gm} / \mathrm{pot})$, T3 $(0.55$ $\mathrm{gm} / \mathrm{pot})$ and Treatment T4 (0.60 gm/pot). Similar to plant height and shoot biomass, root biomass was also significantly $(P \leq 0.001)$ affected among all the various $P$ application on wheat plant.

Root-shoot ratio is an important factor to understand growth responses of plants under elevated $\mathrm{P}$ applications. The root: shoot ratio of the wheat plant with and without treatments at the various level of P supply were analyzed (Table 4). Comparison of different treatment root: shoot ratio showed an increase with the increasing $\mathrm{P}$ application in both varieties of BARI released wheat plants. In the same line, Bhadoria et al. (2002) reported that, phosphate shortage increased root/shoot ratio of wheat, because root development was more higher on elevated P. Similar results were observed in lettuce (Buso and Bliss 1988), and maize (Gaume et al. 2001).

The relationship between shoot biomass and average plant height was analyzed to determine the effect of plant height on the production of biomass of the wheat plant. A significant correlation $\left(\mathrm{R}^{2}=0.92, P<0.05\right)$ between plant height and shoot biomass under elevated $\mathrm{P}$ supply indicated that plant development enhances with the application of $P$ in soil (Fig. 9). Similarly, a significant correlation $\left(R^{2}=0.95, P<0.05\right)$ between plant height and root biomass under elevated $\mathrm{P}$ application was observed. The increase in plant growth is largely due to increase absorption of nutrients from soil solution (Son and Smith 1988). However, the elevated P plays significant role in the growth of the wheat plant. 

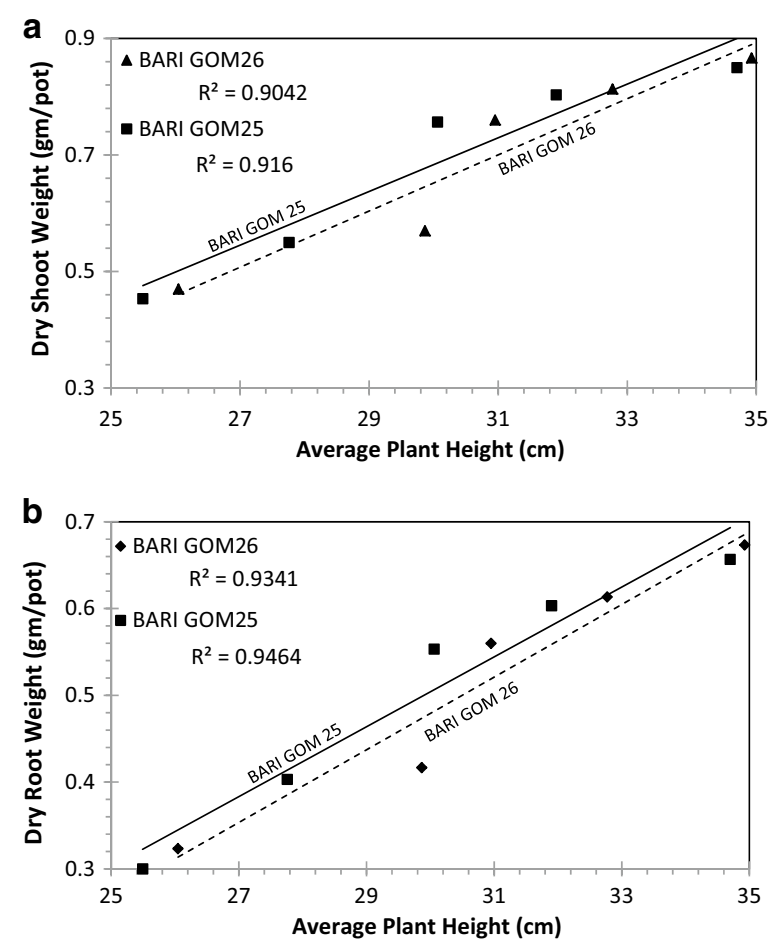

Fig. 9 Relationship between a shoot dry weight and average plant height; $\mathbf{b}$ root dry weight and average plant height of wheat plant

\section{Conclusion}

This study reveals that the elevated $\mathrm{P}$ taken a significant part in the development of the wheat plant in acidic soil. These findings indicate that the added soluble P increases the absorption of nutrients from the soil solution. However, added P is efficient both for increasing shoot development and root growth. Moreover, no varietal difference is found in various experiments. Further extensive research and keen observation of trials are necessary to determine the effects of high phosphorus application. Our next research step is to analyses the plants and soils in order to determine the actual soil phosphorus availability in an alkaline soil.

\section{Authors contributions}

RS carried out the whole research and wrote the manuscript; TI supervised the whole research work by providing necessary logistical support and guidance; RS conducted all the experiments, recorded all the data, collected all the samples and conducted lab analysis. Both authors read and approved the final manuscript.

\section{Author details}

${ }^{1}$ Institute of Biological Sciences, Rajshahi University, Rajshahi, Bangladesh. ${ }^{2}$ Department of Agronomy and Agriculture Extension, Faculty of Agriculture, Rajshahi University, Rajshahi, Bangladesh.

\section{Acknowledgements}

The authors are thankful to the Institute of Biological Sciences, Rajshahi University, Rajshahi for providing Post-graduate Research opportunity and Wheat research Centre, Shampur, Rajshahi for providing wheat plants and Soil Resources Development Institute, Shampur, Rajshahi for testing soil and plants. The authors are also grateful to the Department of Agronomy and Agricultural Extension, Rajshahi University, Rajshahi.

\section{Competing interests}

The authors (RS and TI) declare no competing financial interests. 


\section{References}

Ahmad M, Khan MJ, Muhammad D, Jr A (2013) Response of Wheat (Triticum aestivum L.) to phosphorus application in different soils series having diverse lime content. Int J Agron Plant Prod 4(5):915-927

AOAC (1975) Official methods of analysis, 12th edn. Associationof Official Analytical Chemists, Washington

Armstrong LD (1999) Phosphorus for agriculture. Better Crops Plant Food 83(1):3-39

Bhadoria PS, Steingrobe B, Claassen N, Liebersbach H (2002) Phosphorus efficiency of wheat and sugar beet seedling grown in soils with mainly calcium, or iron and aluminum phosphate. Plant Soil 246:41-52

Biswas A, Alamgir M, Haque SMS, Osman KT (2012) Study on soils under shifting cultivation and other land use categories in Chittagong Hill Tracts, Bangladesh. J Forest Res 12(2):261-265

Buso GSC, Bliss FA (1988) Variability among lettuce cultivars at two levels of availablephosphorus. Plant Soil 111:67-73

Cavagnaro TR, Smith FA, Ayling SM, Smith SE (2003) Growth and phosphorus nutrition of a Paris-type Carbuncular mycorrhizal symbiosis. New Phytol 157:127-134

Conde LD, Chen Z, Chen H, Liao H (2014) Effects of phosphorus availability on plant growth and soil nutrient status in the rice/soybean rotation system on newly cultivated acidic soils. Am J Agric Forest 2(6):309-316

Fageria NK, Baligar VC (1999) Phosphorus-use efficiency in wheat genotypes. J Plant Nutr 22(2):331-340

Fageria NK, Baliger VC, Jones CA (1997) Growth and mineral nutrition of field crops, 2nd edn. Marcel Dekker, Inc, Newyork

Furihata T, Suzuki M, Sakurai H (1992) Kinetic characterization of two phosphate uptake systems with different affinities in suspension-cultured Catharan thusroseus proto plants. Plant Cell Physiol 33:1151-1157

Gaume L, Mächler F, Leon CD, Narro L, Frossard E (2001) Low-P tolerance by maize (Zeamays L.) genotypes: significance of root growth, and organic acids and acid phosphatase root exudation. Plant Soil 228:253-264

Gee GW, Bauder JW (1986) Particle-size analysis. In: Klute A (ed) Methods of soil analysis, part 1. Agronomy monograph No. 9, 2nd edn. ASA and SSSA, Madison, pp 383-411

Hu J, Cui X, Dai J, Wang J, Chen R (2014) Interactive effects of Arbuscular Mycorrhizae and maize (Zea mays L.) Straws on wheat (Triticum aestivum L.) growth and organic carbon storage in a sandy loam soil. Soil Water Res 3:119-126

Huq SMI, Alam MD (2005) A handbook on analyses of soil, plant and water. BACER-DU, University of Dhaka, Dhaka, pp $13-40$

Iqbal T, Sale P, Tang C (2010) Phosphorus ameliorates aluminium toxicity of Al-sensitive wheat seedlings. In: Proceedings of the 2010 19th World Congress of Soil Science, Soil Solutions for a Changing World. [S.I.]:IUSS, Brisbane, pp 92-95

Melese A, Yli-Halla M, Yitaferu B (2015) Effects of lime, wood ash, manure and mineral P fertilizer rates on acidity related chemical properties and growth and P uptake of wheat (Triticum aestivum L.) on acid soil of Farta District Northwestern Highlands of Ethiopia. Int J Agric Crop Sci 8(2):256-269

Pasek MA (2008) Rethinking early earth phosphorus geochemistry. Proc Natl Acad Sci 105(3):853-858

Petersen L (1996) Soil analytical methods soil testing management and development. Soil Resources Development Institute, Dhaka, pp 1-28

Piper CS (1950) Soil and plant analysis. Adelaide University, Hassel Press, Adelaide, p 368

Podder M, Akter M, Saifullah ASM, Roy S (2012) Impacts of plough pan on physical and chemical properties of soil. J Environ Sci Nat Resour 5(1):289-294

Rahim A, Ranjha AM, Rahamtullah, Waraich EA (2010) Effect of phosphorus application and irrigation scheduling on wheat yield and phosphorus use efficiency. Soil Environ 29:15-22

Rubio R, Borie F, Schalchli C, Castillo C, Azcón R (2003) Occurrence and effect of arbuscular mycorrhizal propagules in wheat as affected by the source and amount of phosphorus fertilizer and fungal inoculation. Appl Soil Ecol 23:245-255

Schachtman DP, Reid RJ, Ayling SM (1998) Update on phosphorus uptake phosphorus uptake by plants: from soil to cell. Plant Physiol 116:447-453

Soltanpour PN, Workman S (1979) Modification of the $\mathrm{NH}_{4} \mathrm{HCO}_{3}$-DTPA soil test to omit carbon black. Commun Soil Sci Plant Anal 10:1411-1420

Son CL, Smith SE (1988) Mycorrhizal growth responses: interaction between photon irradiance and phosphorus nutrition. New Phytol 108:305-314

Subbiah BV, Asija GL (1956) A rapid procedure for estimation of available nitrogen in soils. Curr Sci 25:259-260

Syers JK, Johnston AE, Curtin D (2008) Efficiency of soil and fertilizer phosphorus use. FAO Fertilizer and Plant Nutrient Bulletin 18, Rome, pp 5-14

Talboys PJ, Healey JR, Withers PJA, Jones DL (2014) Phosphate depletion modulates auxin transport in Triticum aestivum leading to altered root branching. J Exp Bot 65(17):5023-5032

Ullrich-Eberius Cl, Novacky A, van Bel AJE (1984) Phosphate uptake in Lemnagibba G1: energetics and kinetics. Planta 161:46-52

Walkley A, Black IA (1934) An examination Degtijareff method for determining soil organic matter and a proposed modification of chromic acid titration method. Soil Sci 37:29-38

Whitelaw MA (2000) Growth promotion of plants inoculated with phosphate-solubilizing fungi. Adv Agron 69:99-151

Zheng JS, Yang JL, He YE, Yu XH, Zhang L, You JF, Shen RF, Matsumoto H (2005) Immobilization of aluminum with phosphorous in roots is associated with high aluminum resistance in buckwheat. Plant Physiol 138:297-303 